\title{
Heat induced epitope retrieval for rabies virus detection by direct fluorescent antibody test in formalin-fixed dog brain tissues
}

\author{
God'spower R. Okoh ${ }^{1, *}$, Haruna M. Kazeem ${ }^{2}$, Grace S.N. Kia ${ }^{3,4}$ and Zhakum N. Ponfa ${ }^{5}$ \\ ${ }^{1}$ Department of Veterinary Microbiology, Faculty of Veterinary Medicine, University of Abuja, P.M.B. 117, Nigeria \\ ${ }^{2}$ Department of Veterinary Microbiology, Faculty of Veterinary Medicine, Ahmadu Bello University, Zaria, P.M.B. \\ 1045, Nigeria \\ ${ }^{3}$ Department of Veterinary Public Health and Preventive Medicine, Faculty of Veterinary Medicine, Ahmadu Bello \\ University, Zaria, P.M.B. 1045, Nigeria \\ ${ }^{4}$ Center of Excellence in Neglected Tropical Diseases and Forensic Biotechnology, Ahmadu Bello University Zaria, \\ Nigeria \\ ${ }^{5}$ Central Diagnostic Laboratory, National Veterinary Research Institute, Vom, P.M.B. 01, Nigeria
}

\begin{abstract}
There is a great need for a chemical method of tissue preservation that would allow sample storage for extended periods at room temperature. This study aimed at retrieving and detecting rabies virus antigen by direct fluorescent antibody test (DFAT) in formalin-fixed dog brain tissues. Forty fresh dog brain specimens were collected as paired samples from rabies suspected cases that were received for postmortem detection of rabies in the Central Diagnostic Laboratory, National Veterinary Research Institute, Vom. One portion of each paired sample was prepared for fresh fluorescent antibody testing and the other portion was prepared for epitope retrieval and florescent antibody testing following fixation in $10 \%$ neutral buffered formalin. DFAT on formalin-fixed tissue exhibited a sensitivity of $100 \%$ in comparison to DFAT on fresh-tissue. No false positive result was obtained in formalin-fixed DFAT procedure, demonstrating $100 \%$ specificity. There was no apparent difference in the intensity of fluorescence in DFAT on fresh sample and formalin-fixed DFAT following heat induced epitope retrieval (concordance $=98 \%$; $95 \%$ C.I. 0.9660 to 0.9903). The strength of agreement between DFAT on formalin-fixed and DFAT on fresh tissue was very good (Cohen's kappa coefficient value $=1.000 ; 95 \%$ C.I. 1.000-1.000). This study provides new information on the retrieval of rabies antigen by heat induced epitope retrieval for DFAT on formalinized tissues. Formalin could therefore, be used henceforth to fix tissues of rabies suspected cases for routine diagnosis, transportation or archival purposes. The heat induced epitope retrieval can be routinely used to retrieve rabies virus antigen for DFAT in cases where only formalin-fixed tissues are available or when preservation by freezing is difficult.
\end{abstract}

Keywords: Direct fluorescent test, Formalin-fixed brain tissues, Heat induced epitope retrieval, Rabies virus.

\section{Introduction}

Rabies affects central nervous system (CNS) and death is inevitable once clinical signs set in (Dietzschold et al., 2008). It is caused by rabies virus, a negativestranded ribonucleic acid (RNA) virus of approximately 12 kilo base pairs (kbp) (Zhou et al., 2013; Kia et al., 2018) with cylindrical morphology (bullet-shaped). Rabies virus which is the type species of the genus Lyssavirus and family Rhabdoviridae has a relatively simple, modular genome organization and encodes five structural proteins: a RNA-dependent RNA polymerase (L), a nucleoprotein $(\mathrm{N})$, a phosphorylated protein $(\mathrm{P})$, a matrix protein $(\mathrm{M})$ and an external surface glycoprotein (G) (Finke and Conzelmann, 2005; Dietzschold et al., 2008). Lozano et al. (2012) reported a decrease in mortality due to rabies mostly in Asia and Africa from approximately, 54,000 deaths in 1990 to 26,000 in 2010. In India alone, about 20,000 people die annually from rabies (Harris, 2012). In 2015, approximately 6,000 rabies cases were reported in China and about 5,600 cases were recorded in the Democratic Republic of the Congo (Hampson et al., 2015). The main host for the transmission of rabies virus in most endemic countries especially Asia and Africa is dog and there are no stringent laws in place to ensure compulsory vaccination of dogs. More than 10,000 Nigerians are exposed to rabies annually, and about 1,000 annual cattle mortality had been reported (Tekki et al., 2016). In Nigeria, human and animal rabies cases are on the increase annually despite the availability of vaccines for its control and prevention (Ogunkoya, 2008). Some of the advantages of formalin-fixed procedures are the ease of sample preservation and the reduced risk involved in transporting and processing samples which may contain infectious rabies virus (Wunner and Jackson, 
2010). A potential limitation of the procedure to work with formalin-fixed preparation is the inability to cultivate and amplify the virus from an inactivated sample (Shankar, 2009). Immunofluorescence method applied to formalin fixed tissues was previously significantly less sensitive than the direct fluorescent antibody test (DFAT) method on fresh brain tissues. With recent modifications to achieve better immunofluorescence (Warner et al., 1997, 1999), this procedure may now be as sensitive as DFAT on fresh tissues (Whitfield et al., 2001). The direct rapid immunohistochemistry test (DRIT) was recently developed by the US Centers for Disease Control and Prevention (CDC). It is a rapid tests and results are available approximately one hour. The principle of this promising test is based on the detection of rabies $\mathrm{N}$ protein in formalin-fixed brain smears by the use of very concentrated monoclonal antibodies with streptavidin peroxidase and a substrate coloring agent. This test uses light microscope for visualization of rabies antigen, therefore, can be implemented in the field (Dürr et al., 2008; Fooks et al., 2009; Madhusudana et al., 2012). Although DRIT procedure may be cumbersome, the sensitivity and specificity could reach $100 \%$ when compared to DFAT (Lembo et al., 2006; Madhusudana et al., 2012). There is a great need for a chemical method of tissue preservation that would allow sample storage for extended periods at room temperature. If this were available, a higher proportion of decisions regarding post-exposure immunization could be based upon laboratory data; cumulative surveillance data would be more representative and meaningful; and the infection hazard to laboratory workers would be reduced (Umoh and Blenden, 1981). It was generally felt that chemical preservation with formalin makes DFAT examination virtually impossible. However, with the modification to achieve better immunofluorescence (Warner et al., 1997), this procedure may now be as specific a diagnostic method as DFAT on fresh tissue. Therefore, this study aimed at retrieving and detecting rabies virus antigen by DFAT in formalin-fixed dog brain tissues.

\section{Sample collection}

Materials and Methods

Forty fresh dog brain specimens were collected as paired samples from rabies suspected cases that were received for postmortem detection of rabies in the Central Diagnostic Laboratory, National Veterinary Research Institute, Vom, over a period of three months. Samples were collected from different locations, viz. hippocampus, cerebellum, and brain stem respectively. One portion of each paired sample was prepared for fresh fluorescent antibody testing and the other portion was fixed in $10 \%$ neutral buffered formalin (NBF) at room temperature for a minimum period of three days. The tests were performed in blinded schedules. The
DFAT rabies status analysis of fresh- tissue samples and those of formalin- fixed tissue samples were done blindly until all tests were done (Whitfield et al., 2001).

Heat induced epitope retrieval and the detection of rabies virus antigen in formalin-fixed tissues

Sodium citrate $(2.35 \mathrm{~g})$ and citric acid $(0.42 \mathrm{~g})$ were dissolved in $200 \mathrm{ml}$ of distilled water. Then, the total volume of the mixture was made up to one litre with distilled water in a volumetric flask. The sodium citrate buffer was heated to $92^{\circ} \mathrm{C}$ in a water bath. Formalin fixed brain tissues were removed and washed thoroughly with PBS ( $\mathrm{pH} \mathrm{8.5).} \mathrm{To} \mathrm{prepare} \mathrm{smears,} \mathrm{the}$ samples were crushed in a mortar after which impression smears were made on clean slides. The slides were air dried at room temperature and then fixed by placing in a coplin jar containing acetone at $-20^{\circ} \mathrm{C}$ for 30 minutes. The slides were removed and air dried at room temperature. The slides were then immersed in the staining dish containing the pre-heated sodium citrate buffer $(0.01 \mathrm{M} ; \mathrm{pH} 6.0)$ and incubated at $92^{\circ} \mathrm{C}$ for 30 minutes in a water bath. The staining dish was then removed and slides were allowed to cool at room temperature for 20 minutes. Thereafter, slides were rinsed in PBS ( $\mathrm{pH}$ 8.5) and air dried at room temperature. The slides were transferred to a humidified chamber and a drop of $150 \mu \mathrm{l}$ of fluorescein-labeled monoclonal anti-rabies immunoglobulin (Fujirebio Diagnostics, Inc., U.S) was used for staining. These were then incubated at $37^{\circ} \mathrm{C}$ for 30 minutes. After incubation, the slides were washed three times with Phosphate Buffered Saline (PBS) ( $\mathrm{pH}$ 8.5). The slides were then air-dried at room temperature and arranged in a slide carrier. A drop of $50 \%$ mounting buffered glycerol and a cover slip were applied on each smear. The slides were visualized under a fluorescent microscope (Zeiss International, Germany). Presence of Bright/dull/dim apple green oval or ellipsoid fluorescing intracellular accumulations was considered positive. Fluorescence was scored by two separate individuals using a three-plus scoring system (scores were as follows: $3+++$ bright apple green fluorescence; $2++$ dull apple green fluorescence; $1+\operatorname{dim}$ but detectable apple green fluorescence). DFAT was also carried out on formalinized brain tissues without treatment with sodium citrate buffer.

\section{Rabies antigen detection in fresh brain tissues}

Rabies antigen detection by DFAT was done according to Dean et al. (1996) and Okoh et al. (2018).

\section{Data Analysis}

The results were presented using simple descriptive statistics involving percentages, tables and charts. The concordance coefficient and simple Cohen's kappa coefficient value were used for statistical comparison of the diagnostic tests. All statistical procedures were done using the MedCalc Software (MedCalc Software bvba, Version 17.8). 


\section{Results \\ Heat induced epitope retrieval and the detection of rabies virus antigen in formalin-fixed tissues}

The combined results of the preliminary experiment on formalin-fixed tissues were presented in Table 1 .

Out of the 40 samples tested, $32(80 \%)$ brain samples were positive by DFAT after treatment with sodium citrate buffer and none tested positive without treatment with sodium citrate buffer. The results were not affected by the length of time the tissues were left in formalin.

Table 1. Results of Rabies virus antigen detection in formalin-fixed tissues.

\begin{tabular}{lcc}
\hline DFAT & $\begin{array}{c}\text { with sodium citrate } \\
\text { buffer treatment }\end{array}$ & $\begin{array}{c}\text { without sodium } \\
\text { citrate buffer } \\
\text { treatment }\end{array}$ \\
\hline $\begin{array}{l}\text { Number } \\
\text { Examined }\end{array}$ & 40 & 40 \\
Positive & $32(80 \%)$ & $0(0 \%)$ \\
\hline
\end{tabular}

(DFAT): Direct fluorescent antibody test.

\section{Detection of rabies virus antigen in Fresh dog brain tissues}

Fresh brain tissues (Hippocampus, brain stem and cerebellum) were positive in $32(80 \%)$ cases out of the 40 cases tested using DFAT for the presence of rabies virus antigen. Eight brain samples were negative for rabies virus antigen (Table 2).

Table 2. Rabies antigen detection in fresh brain tissues by direct fluorescent antibody test.

\begin{tabular}{lccc}
\hline $\begin{array}{l}\text { Part of brain } \\
\text { examined }\end{array}$ & $\begin{array}{c}\text { Number } \\
\text { examined }\end{array}$ & $\begin{array}{c}\text { Number } \\
\text { positive }\end{array}$ & Positive (\%) \\
\hline Hippocampus & 40 & 32 & 80 \\
Brain stem & 40 & 32 & 80 \\
Cerebellum & 40 & 32 & 80 \\
\hline
\end{tabular}

\section{Comparison of DFAT on fresh tissue and DFAT on formalin fixed tissue}

As shown in Table 3, 32 brain tissues were positive for rabies antigen by both the DFAT on fresh tissue and the DFAT on formalin-fixed tissue. Thus, DFAT on formalin-fixed tissue exhibited a sensitivity of $100 \%$ in comparison to DFAT on fresh-tissue. No false positive result was obtained in formalin-fixed DFAT procedure, demonstrating $100 \%$ specificity. We found $100 \%$ agreement (32 positives and 8 negatives) between the two techniques. The concordant scores of the two techniques were shown in Table 4 . There was no apparent difference in the intensity of fluorescence in DFAT on fresh sample and formalin-fixed DFAT (concordance $=98 \% ; 95 \%$ C.I. 0.9660 to 0.9903 ) (Fig. 1 and 2).

The strength of agreement (Cohen's kappa coefficient) between DFAT on formalin-fixed and DFAT on fresh tissues was 1.000 ; $95 \%$ C.I. $1.000-1.000$.
Table 3. Sensitivity and Specificity comparison of DFAT on fresh and formalin-fixed tissues.

\begin{tabular}{|c|c|c|c|}
\hline \multirow[t]{2}{*}{ Category } & \multicolumn{2}{|c|}{ DFAT on formalin-fixed tissues } & \multirow[t]{2}{*}{ Total } \\
\hline & Positive & Negative & \\
\hline $\begin{array}{l}\text { DFAT on } \\
\text { fresh samples } \\
\text { (Positive) }\end{array}$ & 32 & 0 & 32 \\
\hline $\begin{array}{l}\text { DFAT on } \\
\text { fresh samples } \\
\text { (Negative) }\end{array}$ & 0 & 8 & 8 \\
\hline Total & 32 & 8 & 40 \\
\hline Sensitivity & & $100 \%$ & \\
\hline Specificity & & $100 \%$ & \\
\hline
\end{tabular}

Table 4. Concordant Scores for Rabies virus detection by direct fluorescent antibody test in fresh and formalin-fixed dog brain tissues.

\begin{tabular}{lcc}
\hline Concordant Score & DFAT $_{\mathrm{a}}$ & DFAT $_{\mathrm{b}}$ \\
\hline $3(+++)$ & 24 & 26 \\
$2(+++)$ & 8 & 6 \\
$1(+)$ & 0 & 0 \\
0 (Negative) & 8 & 8 \\
\hline Total & 40 & 40 \\
\hline
\end{tabular}

$\left(\right.$ DFAT $\left._{\mathrm{a}}\right)$ : Direct fluorescent antibody test on formalin-fixed dog brain tissues. $\left(\mathrm{DFAT}_{\mathrm{b}}\right.$ ): Direct fluorescent antibody test on fresh dog brain tissues.

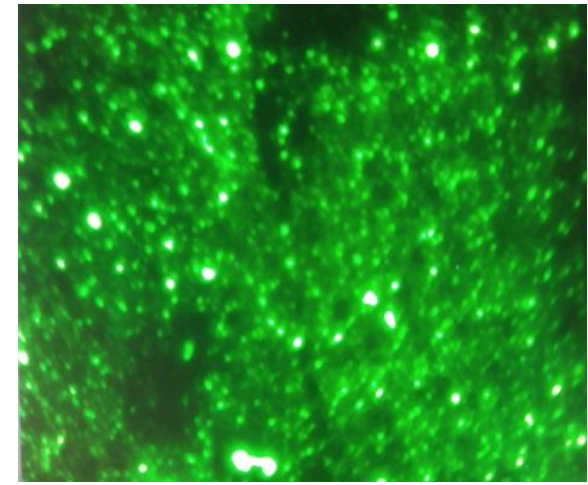

Fig. 1. Apple green fluorescing intracellular accumulation of fresh brain smear. Stained with Fluorescein-labeled monoclonal anti-rabies immunoglobulin $\times 400$.

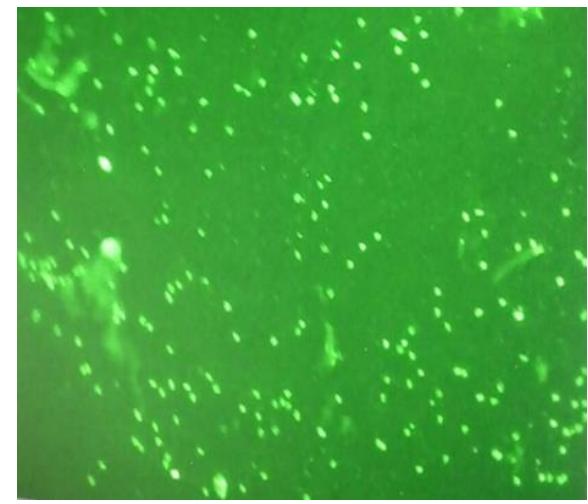

Fig. 2. Apple green fluorescing intracellular accumulation of formalin-fixed brain smear after treatment with heated sodium buffer $(0.01 \mathrm{M}, \mathrm{pH}$ 6.0). Stained with Fluoresceinlabeled monoclonal anti-rabies immunoglobulin $\times 400$. 


\section{Discussion}

Several researchers have made attempts to detect rabies virus antigen in formalin-fixed tissues using DFAT staining procedures (Bourhy and Sureau, 1990; Warner et al., 1997; Whitfield et al., 2001). All of these studies reported challenges in the tests without the use of antigen retrieving agents. The results presented in this study demonstrated $100 \%$ sensitivity and specificity of the formalin-fixed DFAT procedure. This agrees with the finding of Whitfield et al. (2001) who recorded $99.8 \%$ sensitivity and $100 \%$ specificity of formalinfixed DFAT.

However, a lower sensitivity of formalin-fixed DFAT following enzymatic digestion with trypsin was reported in previous study (Umoh and Blenden, 1981). This suggests that heat induced epitope retrieval (HIER) procedure could be a better alternative to enzyme digestion for the retrieval rabies virus antigen in DFAT procedure on formalin-fixed.

Formalin fixation forms protein cross-links that mask the antigenic sites in tissues, thereby giving weak or false negative result for DFAT rabies detection (Warner et al., 1997). Antigen retrieval with heated sodium citrate buffer breaks these protein cross-links and exposes antigenic sites, allowing antibody to bind. In this study, $80 \%$ of formalin-fixed tissues tested positive for rabies virus antigen by DFAT after treatment with heated sodium citrate buffer ( $\mathrm{pH}$ 6.0-6.2). All the fixed tissues tested negative to rabies virus antigen by DFAT without sodium citrate buffer treatment. This shows that HIER procedure can be routinely used to retrieve rabies virus antigen for DFAT in cases where only formalin-fixed tissues are available or when preservation by freezing is difficult.

Formalin-fixed DFAT would be useful in instances where rabies is not considered in the diagnosis of an encephalitic condition until after tissue samples have been placed in buffered formalin (Umoh and Blenden, 1981; Mani and Madhusudana, 2013). The technique should also be especially useful in developing countries where poor refrigeration facilities and tropical heat combine to cause rapid deterioration of tissue samples. It is also important to note that the shipping and handling of formalin-preserved tissues is safer for all persons who come into direct or indirect contact with them (Umoh and Blenden, 1981).

In this study, fresh brain tissues were positive in $80 \%$ cases tested for the presence of rabies virus antigen by DFAT. Although, the intensity of fluorescence showed no apparent difference in the different parts of the brain, the size of fluorescence varied and ranged from large oval to small dust like particles. This finding was also observed by Raju et al. (2008) who also suggested that thorough examination of impression smears of various anatomic location of the brain is needed for a reliable diagnosis by DFAT. A concordance coefficient of $98 \%$
(95\% C.I. 0.9660 to 0.9903 ) was recorded for DFAT on fresh and formalin-fixed brain tissues which indicate no apparent difference in the intensity of fluorescence of DFAT on fresh sample and formalin-fixed DFAT. The Cohen's kappa coefficient value of DFAT on formalinfixed tissue relative to DFAT on fresh tissue was 1.000 (95\% C.I. 1.000-1.000) which shows a very good strength of agreement between the two techniques. These further attest to the accuracy and reliability of formalin-fixed DFAT.

\section{Conclusion}

Although the HIER has been used for antigen retrieval from formalin-fixed tissues in Immunohistochemistry, this study provides new information on the retrieval of rabies antigen by HIER for DFAT on formalinized tissues. Thus, formalin can henceforth be used for the preservation of rabies suspected tissues and subsequently retrieved by HIER procedure when preservation by freezing may be challenging or whenever there are safety concerns during transportation. Our study also indicates that HIER procedure can be routinely used to retrieve rabies virus antigen for DFAT in cases where only formalin-fixed tissues are available. The HIER procedure is easy to apply and suitable for tropical countries with limited electricity since it does not require refrigeration. This study also shows that formalin-fixed DFAT is as valid and reliable procedure for rabies diagnosis as the DFAT on fresh samples and would be useful in cases where the current standard techniques cannot be used.

\section{Acknowledgements}

The authors wish to thank Dr. Yakubu Dashe and Dr. I.S. Tekki of the Central Diagnostic Laboratory, National Veterinary Research Institute (NVRI), Vom for their immense support. We also wish to appreciate Mr. Livinus Clement for the technical support he provided during the course of this work. The authors would like to extend a sincere gratitude to Prof. AbdulDahiru El-Yuguda, Prof. C.N. Kwanashe, Prof. Balarabe Magaji Jahun, and Dr. Adamu Jibril for their timely and useful contributions to the research write up.

\section{Conflict of interest}

The authors declare that there is no conflict of interest.

\section{References}

Bourhy, H. and Sureau, P. 1990. Laboratory Methods for Rabies Diagnosis. Collection of Institute Louis Pasteur, Pari France, pp: 154-197.

Dean, D.J., Abelseth, M.K. and Atanasiu, P. 1996. The fluorescent antibody test. In: Meslin, F.X., Kaplan, M.M. and Koprowski, H. (ed.), Laboratory techniques in rabies, $4^{\text {th }}$ ed. WHO, Geneva, Switzerland, pp: 88-93.

Dietzschold, B., Jianwei, L., Milosz, F. and Matthias, S. 2008. Concepts in the pathogenesis of rabies. Future Virol. 3, 481-490. 
Dürr, S., Naïssengar, S., Mindekem, R., Diguimbye, C., Niezgoda, M., Kuzmin, I., Rupprecht, C.E. and Zinsstag J. 2008. Rabies Diagnosis for Developing Countries. PLoS Negl. Trop. Dis. 2, 206.

Finke, S. and Conzelmann, K.K. 2005. Replication strategies of rabies virus. Virus Res. 111, 120-131.

Fooks, A.R., Johnson, N., Freuling, C.M., Wakeley, P.R., Banyard, A.C., McElhinney, L.M., Marston, D.A., Dastjerdi, A., Wright, E., Weiss, R.A. and Müller, T. 2009. Emerging technologies for the detection of rabies virus: challenges and hopes in the 21st century. PLoS Negl. Trop. Dis. 3, 530.

Hampson, K., Coudeville, L., Lembo, T., Sambo, M., Kieffer, A., Attlan, M., Barrat, J., Blanton, J.D., Briggs, D.J., Cleaveland, S., Costa, P., Freuling, C.M., Hiby, E., Knopf, L., Leanes, F., Meslin, F.X., Metlin, A., Miranda, M.E., Müller, T., Nel, L.H., Recuenco, S., Rupprecht, C.E., Schumacher, C., Taylor, L., Vigilato, M.A.N., Zinsstag, J. and Dushoff, J. 2015. Estimating the Global Burden of Endemic Canine Rabies. PLoS Negl. Trop. Dis. 9, e0003709.

Harris, G. 2012. Where Streets Are Thronged with Strays Baring Fangs, New York Times. Retrieved 6 August 2012.

Kia, G.S.N., Huang, Y., Zhou, M., Zhou, Z., Gnanadurai, C.W., Leysona, C.M., Umoh, J.U., Kazeem, H.M., Ehizibolo, D.O., Kwaga, J.K.P., Nwosu, C.I. and Fu, Z.F. 2018. Molecular Characterization of a Rabies Virus Isolated from Trade Dogs in Plateau State, Nigeria (2018). Sokoto J. Vet. Sci. 16(2), 54-62.

Lembo, T., Niezgoda, M., Velasco-Villa, A., Cleaveland, S., Ernest, E. and Rupprecht, C.E. 2006. Evaluation of a Direct, Rapid Immunohistochemistry Test for Rabies Diagnosis. Emerg. Infect. Dis. 12, 310-313.

Lozano, R., Naghavi, M., Foreman, K., Lim, S., Shibuya, K., Aboyans, V., Abraham, J., Adair, T. and Aggarwal, R. 2012. Global and regional mortality from 235 causes of death for 20 age groups in 1990 and 2010: a systematic analysis for the Global Burden of Disease Study 2010. Lancet 380, 2095-2128.

Madhusudana S.N., Subha, S., Thankappan, U. and Ashwin, Y.B. 2012. Evaluation of a direct rapid immunohistochemical test (dRIT) for rapid diagnosis of rabies in animals and humans. Virol. Sin. 27, 299-302.

Mani, R.S. and Madhusudana S.N. 2013. Laboratory
Diagnosis of Human Rabies: Recent Advances. Sci. World J. pp: 1-10.

Ogunkoya, A.B. 2008. Review of Rabies and Problems of Rabies in Nigeria. In the Proceedings of the National Conference/workshop on Rabies, IDRABU, Zaria, Nigeria pp: 62-70.

Okoh, G.R., Kazeem, H.M., Kia, G.S.N. and Mailafia, S. 2018. Evaluation of Enzyme Linked ImmunoSorbent Assay and Rapid Immuno-Diagnostic Test for Rabies Antigen Detection in Archived Dog Brain Tissues. Folia Vet. 62, 18-24.

Raju, S., Saseendranath, M.R. and Tresamol, P.V. 2008. Comparing the sensitivity of detecting viral antigen in different parts of rabies suspected brain using fluorescent antibody test. Turk. J. Vet. Anim. Sci. 39, 18-19.

Shankar, B.P. 2009. Advances in Diagnosis of Rabies. Vet. World 2, 74-78.

Tekki, I.S., Ponfa, Z.N., Nwosuh, C.I., Kumbish, P.R., Jonah, C.L., Okewole, P.A., Shamaki, D. and Ahmed, S.M. 2016. Comparative assessment of seller's staining test (SST) and direct fluorescent antibody test for rapid and accurate laboratory diagnosis of rabies. Afri. Health Sci. 16, 123-127.

Umoh, J.U. and Blenden, D.C. 1981. Immunofluorescent staining of rabies virus antigen in formalin-fixed tissue after treatment with trypsin. Bull. WHO 59, 737-744.

Warner, C.K, Fekadu, M., Whitfield, S. and Shaddock, J. 1999. Use of anti-glycoprotein monoclonal antibodies to characterize rabies in formalin-fixed tissues. J. Virol. Methods 77, 69-74.

Warner, C.K., Whitfield, S.G., Fekadu, M. and Ho, H. 1997. Procedures for reproducible detection of rabies virus antigen mRNA and genome in situ in formalin-fixed tissues. J. Virol. Methods 67, 5-12.

Whitfield, S.G., Fekadu, M., Shaddock, J.H., Niezgoda, M., Warner, C.K. and Messenger, S.L. 2001. A comparative study of the fluorescent antibody test for rabies diagnosis in fresh and formalin-fixed brain tissue specimens. J. Virol. Methods 95, 145151.

Wunner, W.H. and Jackson, A.C. 2010. Rabies: Scientific Basis of the Disease and Its Management. Academic Press, pp: 411-470.

Zhou, M., Zhou, Z., Kia, G.S.N., Gnanadurai, C.W., Leyson, C.M., Umoh, J.U., Kwaga, J.P., Kazeem, H.M. and Fu, Z.F. 2013. Complete Genome Sequence of a Street Rabies Virus Isolated from a Dog in Nigeria. Genome Announc. 1, e00214-12. 